\title{
The Immunomodulatory Functions of Mesenchymal Stromal/Stem Cells Mediated via Paracrine Activity
}

\author{
Yueyuan Zhou ${ }^{1,2}$, Yusuke Yamamoto ${ }^{2}$, Zhongdang Xiao ${ }^{1}$ and Takahiro Ochiya ${ }^{2,3, *}$ \\ 1 State Key Laboratory of Bioelectronics, School of Biological Science and Medical Engineering, \\ Southeast University, Nanjing 210096, China \\ 2 Division of Cellular Signaling, National Cancer Center Research Institute, 5-1-1 Tsukiji, Chuo-ku, \\ Tokyo 104-0045, Japan \\ 3 Department of Molecular and Cellular Medicine, Institute of Medical Science, Tokyo Medical University, \\ 6-1-1 Shinjuku, Shinjuku-ku, Tokyo 160-8402, Japan \\ * Correspondence: tochiya@ncc.go.jp; Tel.: +81-3-3342-6111 (ext. 6168)
}

Received: 17 June 2019; Accepted: 11 July 2019; Published: 12 July 2019

\begin{abstract}
Mesenchymal stromal/stem cells (MSCs) exist in almost all tissues, possessing the potential to differentiate into specialized cell types and exert immunomodulatory functions. Thus, they have attracted much attention as a promising therapeutic candidate. Recent studies have demonstrated that paracrine signaling is mainly responsible for the involvement of MSCs in the modulation of immune responses and the progression of diseases. Through release of secretome consisting of a diverse range of cytokines, chemokines, and extracellular vesicles (EVs), MSCs convey regulatory messages to recipient immune cells in the microenvironment. In this review, we focus on the recent advances in how MSCs contribute to immunomodulation through the secretion of paracrine factors. The further improved understanding of the molecular mechanism underlying the interactions between MSCs and immune cells highlights the paracrine biology of MSCs in the modulation of the immune microenvironment and promotes the clinical application of MSCs in regenerative medicine and immune diseases.
\end{abstract}

Keywords: MSC; immune regulation; paracrine mechanism; immune diseases

\section{Introduction}

Mesenchymal stromal/stem cells (MSCs) were initially identified based on their clonogenic capability in guinea-pig bone marrow and called colony-forming unit-fibroblasts (CFU-F) [1] Subsequently, morphologically similar fibroblast-like cells were readily isolated from both fetal and adult sources, such as the umbilical cord, adipose tissue, skin, dental pulp and liver [2-5]. These cells have a specific surface-molecule phenotype, being positive for CD105, CD73, and CD29 expression and negative for CD31, CD34, CD45, CD14 and human leukocyte antigen (HLA)-DR expression, according to the criteria proposed by the International Society for Cellular Therapy (ISCT) [6]. MSCs were further shown to possess self-renewing potential and to differentiate into multiple mesodermal cell lineages under specific experimental and physiological conditions, which made them an alternative source in tissue repair and regenerative medicine [7-9]. In addition to transdifferentiation, the paracrine effects of MSCs are frequently correlated with the therapeutic benefits of these cells [10-12]. MSCs contribute to cell migration/stimulation, angiogenesis, and antiapoptotic processes through releasing various types of secretome. In particular, it was recently demonstrated that MSCs play a critical role in regulating the inflammatory microenvironment and interacting with immune cells, including $\mathrm{T}$ cells, $\mathrm{B}$ cells, natural killer (NK) cells, and dendritic cells (DCs) $[13,14]$. The cross talk and interplay of MSCs and local environment reversely control and regulate the paracrine activity of MSCs $[15,16]$. Therefore, 
the paracrine potency might vary with sources and microenvironment of MSCs. MSCs isolated from fetal tissues such as umbilical cord (UC) and UC-blood (UCB) were shown to have increased secretion of proinflammatory proteins and growth factors than MSCs obtained from adult adipose tissue or bone marrow $[17,18]$. Despite the transplantation of the same human UCB-derived MSCs (UCB-MSCs), the protective benefits are associated with significant upregulation of vascular endothelial growth factor (VEGF) and hepatocyte growth factor against hyperoxic conditions in neonatal lung injury model [19]. Due to their immunomodulatory properties, MSCs hold beneficial promise in the treatment of allograft rejection episodes, as well as the suppression of abnormal immune responses in autoimmune and inflammatory diseases. MSCs have emerged as a more appropriate option for cell therapy because of their easier isolation procedures, great expansion ability and biosafety profile, and lower ethical challenges, as well as lower risk of tumorgenicity compared to other cell sources [20,21]. Preclinical animal studies of MSC therapy have been conducted in organ transplantation, graft-versus-host disease (GVHD), multiple sclerosis, hepatic failure, lung injury, diabetes and rheumatoid arthritis [22-28]. The preclinical data raise the notable expectation of the application of MSCs in human projects; however, the clinical outcomes of advanced trials fell short of expectations compared to the outcomes in animal models due to many challenges that still remain to be overcome prior to the efficient clinical application of MSC-based therapy. Several issues, including the suitable source, the well-characterized population, and the clearly-determined functions of MSCs, are critical to achieve the appropriate therapeutic effects. The paracrine products of MSCs are considered as the alternative to cell-based therapy as cell-free therapy. The secretome of MSCs differs depending on the tissue from which the MSCs are obtained, and substantial variation between donors and in response to different culture conditions $[29,30]$. Although there a number of reports of improved outcomes from the clinical application of MSCs, the evidence to date has not supported the conclusion that they are effective therapy. Therefore, it is critical to explore the in-depth mechanisms of MSCs involved in the immune system, especially their paracrine biology, including the regulation and mechanism of secretion of soluble factors and extracellular vesicles (EVs).

\section{Paracrine Hypothesis of MSCs}

Intramyocardial injection of stem cells has been extensively proven to offer therapeutic benefits in infarct repair by promoting myocardium regeneration in animal models and clinical trials [31-33]. The mechanisms underlying stem cell therapy have largely been attributed to the paracrine actions of stem cells that are independent of their differentiation capability, as transdifferentiation is extremely rare under physiological conditions. This recognition stemmed from studies that showed that the efficiencies of myocardial recruitment and engraftment after local or systemic stem cell transplantation were typically too low to account for functional improvement [34-36]. It was firstly found that paracrine effects rather than transdifferentiation contribute to the functional benefits derived from MSCs in heart disease mouse models. Although it was found that transplanted MSCs derived from the bone marrow (BM-MSCs) did not undergo overt cardiomyogenic differentiation after direct injection into injured adult mouse hearts, they did improve cardiac function [37]. Subsequently, it was proposed that the production and secretion of cytoprotective factors accounts for stem cell actions in tissue protection and repair. Modified rat BM-MSCs overexpressing the survival gene Akt1 (Akt-MSCs) were shown to prevent ventricular remodeling and restore cardiac function in less than $72 \mathrm{~h}$ through protection of the ischemic myocardium by paracrine mediators released in situ by the BM-MSCs [19]. Furthermore, it was reported by the same group that conditioned medium (CM) from hypoxic Akt-MSCs markedly inhibited hypoxia-induced apoptosis and triggered vigorous spontaneous contraction in adult rat cardiomyocytes in vitro, and significantly limited infarct size and improved ventricular function in vivo. This finding was supported by the results for several genes, such as vascular endothelial growth factor (VEGF), hepatocyte growth factor (HGF), and thymosin b4 (TB4), which exhibited obviously upregulated expression in the Akt-MSCs, supporting the paracrine hypothesis [38]. Similarly, it was demonstrated that intravenous human MSCs (hMSCs) reduced the acute inflammatory response 
and infarct size and improved cardiac function in mouse myocardial infarction models, although a major population of the injected hMSCs were found to be trapped in the lungs [39]. Noninvasive intramuscular administration of BM-MSCs and MSC-CM has been reported to significantly improve ventricular function through trophic factors in a hamster heart failure model [40]. Other studies compared EV-rich fractions to CM and further indicated that EVs were responsible for the therapeutic benefits of MSC-CM [41,42]. Paracrine function has not only emerged as a mode of action of MSCs but has also inspired promising clinical applications of cytokines in regeneration and immunology. The use of MSC-secretome has advantages over the implantation of the MSCs themselves: components can be bio-modified and scaled to specific dosages, and can be stored and transported stably due to their non-living nature. However, since the components and therapeutic potency of the secretome can be influenced by cell sources, pre-conditions, isolation methods and storage conditions, there is an urgent need for standardizing the bioprocessing parameters.

\section{MSC-Mediated Immunoregulation of Immune Cells via Paracrine Actions In Vitro}

It was first reported that MSCs play a critical role in the regulation of immune cells by Juneja et al. in 1986, and their study found that MSCs interacted with a monoclonal human B-lymphoblastoid cell line (UTMB-460) and participated in the establishment of the UTMB-460 cell line [43]. Subsequently, the immunoregulatory function of MSCs was gradually investigated in various studies. However, the full elucidation of mechanisms remains a matter for debate and exploration. Generally, it is hypothesized that transdifferentiation, cell-cell contact and fusion, paracrine effects, extracellular microvesicles (EVs) and mitochondrial transfer are involved in the immunomodulatory roles of MSCs $[10,38,44-46]$. Based on the observation that BM-MSCs strongly suppress T lymphocyte proliferation due to the production of soluble factors, emerging evidence suggests that the secretion of bioactive factors, including chemokines and cytokines, contributes to the broad effects of MSCs on the cells of the innate and adaptive immune systems [47] (Figure 1).

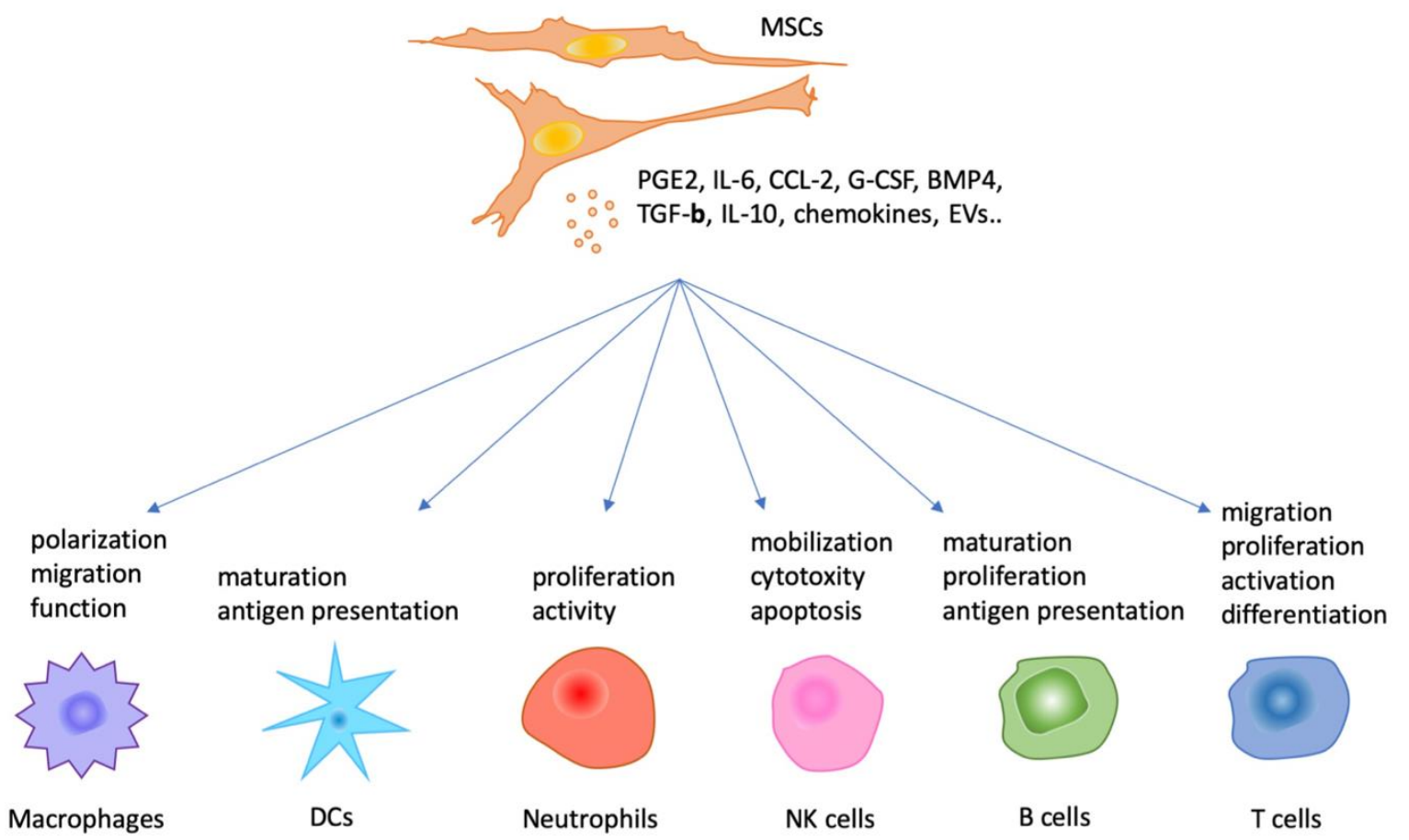

Figure 1. The regulatory function of mesenchymal stromal/stem cells (MSCs) via paracrine on immune cells.

\subsection{MSCs and Innate Immunity}

Macrophages are effector cells of the innate immune system that are crucially involved in the clearance of pathogens in the initiation and resolution of immune responses [48-50]. MSCs affect 
the maturation, migration, polarization and function of macrophages by releasing factors, therefore affecting the strength and duration of immune responses and mediating tissue injury repair. It has been reported that BM-MSCs activated by lipopolysaccharide (LPS) or tumor necrosis factor-a (TNF-a) reprogram macrophages to increase the production of interleukin-10 (IL-10) by secreting prostaglandin E2 (PGE2) and attenuate sepsis and improve survival in mouse sepsis models [51]. Tumor-resident MSCs release a large amount of various chemokines, including CCL-2, CCL-7 and CCL-12, thereby enhancing the recruitment of monocytes expressing CCR2 into tumor sites and increasing the number of macrophages and growth of tumors [52]. In addition, transplanted mouse MSCs recruit M2 macrophages in a stromal cell-derived factor 1 (SDF-1)-dependent manner, which in turn promotes beta cell regeneration through the Wnt/b-catenin pathway in diabetic mouse models [53]. Human placental MSCs have been shown to polarize macrophages from an inflammatory M1 phenotype into an anti-inflammatory M2 phenotype via glucocorticoid receptor (GR) and progesterone receptor (PR) [54]. Overall, the preferential shift in macrophage phenotype from M1 to M2 mediated by MSCs may be closely related to immunoregulation and inflammatory diseases.

Dendritic cells (DCs) are the main antigen-presenting cells in the mammalian immune system. MSC supernatants inhibit CD83 expression, decrease the production of IL-12 and interfere with endocytosis during DC maturation [55]. Additionally, MSCs block the differentiation of CD14+ CD1aprecursors into dermal/interstitial DCs without affecting the generation of CD1a+ Langerhans cells. Consistent results have shown that MSCs also completely prevent the generation of immature DCs from monocytes via IL-6, M-CSF or other soluble factors [56]. A study also reported that MSCs inhibited the differentiation of DCs from bone marrow progenitors in part through the secretion of IL-6 [57]. IL-10 is a common immunosuppressive cytokine, and downstream signaling via the JAK-STAT pathway has been shown to be involved in DC differentiation and maturation. It has also been reported that MSCs inhibit the maturation of DCs through the stimulation of IL-10 secretion and the JAK1/STAT3 signaling pathway. In addition to IL-10, TNF-a-stimulating gene-6 (TSG-6) secreted by MSCs has been demonstrated to suppress MAPK and NF-kB signaling activation during the maturation of immature DCs into mature DCs induced by LPS [58]. These results suggest that MSCs maintain DCs in an immature or semimature suppressor phenotype. Intriguingly, it has been shown that in addition to the aspect of maturation, DC migratory abilities in response to CCL19 are also prevented by MSCs, thus interfering with DC antigen presentation $[59,60]$. Taken together, these findings indicate that MSCs disrupt the three major functions of DCs, namely, the upregulation of antigen presentation and costimulatory molecule expression, the ability to present defined antigens, and the capacity to migrate.

Neutrophils have emerged as short-lived effector cells of the innate immune system and play primary roles in the activation, orientation, and expression of adaptive immune responses [61]. When cocultured with MSCs, neutrophils are protected from apoptosis via IL-6, which is produced by the MSCs and involved in the STAT3 signaling pathway [62]. CCR2 is a chemokine receptor that is abundantly expressed on neutrophils, and TNF-a-activated MSCs secrete large amounts of CXCR2 ligands, such as CXCL1, CXCL2 and CXCL8. It has been demonstrated that MSCs recruit neutrophils through these CXCR2 ligands and that the recruited neutrophils in turn enhance tumor metastasis [63]. Furthermore, LPS-activated MSCs have been shown to augment the antimicrobial effects of neutrophils by releasing IL-8 and macrophage migration inhibitory factor (MIF) [64]. In addition to affecting the mobilization and infiltration of neutrophils, MSCs have been found to suppress unstrained neutrophil activation via increased production of superoxide dismutase (SOD3), thus attenuating neutrophil-mediated tissue damage [65]. This discovery provides insight into the application of MSC-mediated protective functions via a paracrine mechanism.

Natural killer (NK) cells are the major effector cells of the innate immune system and are endowed with the capability to kill virally infected, stressed or cancerous cells [66]. MSCs can inhibit the IL-2-induced proliferation of inactivated NK cells; moreover, MSCs are lysed by activated NK cells. IFN-y-treated MSCs can prevent the NK-mediated cytolytic effects on MSCs by increasing the expression of HLA class I on MSCs [67]. A further investigation demonstrated that MSCs altered 
the phenotype of NK cells and suppressed proliferation and cytokine secretion partly by secreting soluble factors, including transforming growth factor-b1 (TGF-b1) and PGE2 [68]. It was shown that indoleamine 2,3-dioxygenase (IDO) and PGE2 exert a synergistic effect on NK cells to help mediate the inhibition induced by MSCs [69]. In addition, HLA-G5 released by MSCs was reported to contribute to the immunosuppressive properties of MSCs and to inhibit NK cell-mediated cytolysis [70]. In fact, MSCs do not simply play a suppressive role in the regulation of NK cells. It has been revealed that MSCs enhance the ability of NK cells to produce and secrete IFN-y, an effect in part dependent on the soluble factors derived from MSCs as shown by the observation that conditioned medium from MSCs upregulates the expression level of IL-12b1 on the NK cell surface and the phosphorylation of STAT4 in NK cells [71]. It has also been reported that MSCs derived from Wharton's jelly significantly increase the expansion of NK cells isolated from umbilical cord blood in the presence of IL-2, IL-15, IL-3, and FLT-3L [72]. In conclusion, although the mechanisms underlying the interaction between MSCs and NK cells remain unknown and are still under investigation, it can be suggested that paracrine effects are involved in the immunoregulation, at least in part, according to several studies.

\subsection{MSCs and Adaptive Immunity}

$\mathrm{T}$ cells are viewed as the primary cellular effectors of the adaptive immune system and play critical roles in antigen specificity and memory-associated cognate immunity $[73,74]$. When cocultured with MSCs, peripheral blood mononuclear cells (PBMCs) exhibit suppressed proliferation even without cell-cell contact, suggesting that the suppressive effects of MSCs are mediated through the release of soluble bioactive factors. A study demonstrated that HGF, IL-10, and TGF-b1 were involved in the immunosuppression of MSCs at varying concentrations in vitro. The proinflammatory cytokine IFN-y increased HGF and TGF-b1 levels, induced the expression of IDO, and contributed to MSC-mediated allosuppression $[75,76]$. A previous study revealed that the proliferation rate of PBMCs was inhibited $50 \%$ to $60 \%$ by human MSCs releasing suppressive cytokines, including IL-10. Furthermore, PGE2 was shown to be responsible for many of the human MSC-mediated immunomodulatory effects observed in vitro [77]. Mechanically, Toll-like receptors (TLRs) expressed by MSCs, particularly TLR3 and TLR4, function in inducing the activation of NF-kB and the production of cytokines, such as IL-6, and chemokines, such as CXCL10 and IL-8. Therefore, TLR3 or TLR4 ligation on MSCs participates in their immunosuppressive effect on T lymphocyte proliferation [78]. Consistently, it has been reported that TLRs expressed on MSCs affect the expression of cytokines including TNF-a, IL-12, and IL-1b, which has been demonstrated to be involved in DC activation and cytotoxic T cell activity [79]. In contrast, TLR2 does not affect the immunosuppressive effect exerted by murine MSCs on T cell proliferation [80]. One explanation may be that human and mouse models are different. Another recent study demonstrated that MSCs exerted different modulatory effects via a paracrine mechanism on various types of T cell subpopulations. MSC-secreted PGE2 and TGF-b1 were shown to induce $\mathrm{CD}^{+}{ }^{+} \mathrm{CD} 25^{+} \mathrm{FoxP}^{+} \mathrm{T}$ cells $[81,82]$. Similarly, HLA-G5 secreted by MSCs contributes to the suppression of allogeneic $\mathrm{T}$ cell proliferation and $\mathrm{CD}^{+} \mathrm{CD} 25^{\text {high }} \mathrm{FoxP}^{+}$regulatory $\mathrm{T}$ cell (Treg) expansion [70]. It has been found that MSCs inhibit CD4 Th17 cell activation via the release of CCL2 mediated by suppressing the STAT3 signaling pathway in encephalomyelitis mouse models [83]. In addition, MSCs inhibit Th17 cell but not Treg differentiation partly through the secretion of PGE2 and IDO [84]. In addition to their direct effects on T cells, MSC-derived paracrine factors also influence $\mathrm{T}$ cells by regulating innate immune cells, including macrophages and DCs. It is required for T cell activation that costimulatory ligands interact with TCR on T cells. Thus, MSC-produced soluble factors can affect the expression of costimulatory ligands by APCs (antigen-presenting cells), thereby modulating T cells. For instance, MSCs affect the polarization of macrophages, thus controlling the differentiation of $\mathrm{T}$ cells and ultimately exerting an immunomodulatory function [85]. Collectively, the paracrine factors of MSCs convey regulatory messages to T cells through direct and/or indirect mechanisms, thereby participating in the adaptive immune system. 
B cells are another major cell type involved in adaptive immune responses, acting as antigen presenters and antibody producers $[86,87]$. They provide costimulatory signals, secrete cytokines, affect lymphoid tissue structure and organize the splenic architecture, resulting in influences on other immune cells [88,89]. Through cell-cell interactions, MSCs facilitate AKT phosphorylation and inhibit caspase-3-mediated apoptosis in peripheral CD19+ B cells dependent on the increased expression of vascular endothelial growth factor (VEGF) [90]. Aside from direct contact, MSCs derived from adipose tissue also promote the chemotaxis and motility of B cells through the secretion of chemotactic factors. However, B cell-related chemokines produced by MSCs, including PGE2, CXCL8, CXCL10 or combinations, are not responsible for B cell chemotaxis [91]. It has been reported that MSCs inhibit B cell proliferation via cell cycle arrest in the G0/G1 phase mainly mediated by the release of soluble factors. Furthermore, MSCs downregulate the production of immunoglobulins such as IgM, IgG and IgA and decrease the expression of CXCR4, CXCR5 and CXCR7 in B cells. However, MSCs do not affect the expression of molecules involved in antigen presentation by activated B cells [13]. Similarly, it has been demonstrated that MSCs arrest the cell cycle of B cells in the G0/G1 phase. In addition, MSCs block B cell differentiation and modify the activation pattern of extracellular responses and the p38 mitogen-activated protein kinase pathways in B cells [92]. Compared to normal BM-MSCs, BM-MSCs from lupus model mice and systemic lupus erythematosus (SLE) patients show a functional defect resulting in normal B cell inhibition generally due to a reduction in CCL12 expression [93]. Interestingly, recent studies revealed that MSCs could also have a supportive influence on B cells. When cocultured with human umbilical cord-derived MSCs (UC-MSCs), B cells exhibited significant increases in proliferation and terminal differentiation marked by the expression of CD138. In addition, the UC-MSCs promoted immunoglobulin production in the B cells. The immunomodulatory effect of the UC-MSCs on the B cells was partly mediated by PGE2 but not by IL-6 [94]. Granulocyte colony-stimulating factor (G-SCF) suppresses the production of B cell trophic factors (CXCL12, IL-6, IL-7 and insulin-like growth factor-1) secreted by BM-MSCs, leading to a shift from lymphopoiesis to myelopoiesis [95]. The controversial effects of the paracrine activity of MSCs on B cells lack full understanding and merit further investigation.

\subsection{Roles of Extracellular Vesicles}

It is widely believed that the immunomodulatory function of MSCs is largely mediated by paracrine signals. Several recent studies have indicated that the regulatory effects are also partially supported by secreted extracellular vesicles (EVs). Moreover, MSC-secreted EVs (MSC-EVs) are increasingly recognized as key paracrine factors in addition to soluble factors. MSC-EVs, including microvesicles and exosomes, are a heterogeneous population of lipid membrane-encapsulated nanoparticles carrying various biomolecules, such as RNAs (mRNAs and miRNAs) and proteins (membrane receptors, enzymes, cytokines and growth factors) [96]. They play critical roles in cell-cell interactions via local or distant transfer of their bioactive cargoes from parental cells to recipient cells $[97,98]$. Since EVs inherit content from parental MSCs, they possess immunoregulatory characteristics or, in other words, MSCs display immunomodulation dependent on the release of EVs. It has been reported that MSC-EVs induce the M2 macrophage phenotype through mitochondrial transfer dependent on macrophage oxidative phosphorylation in acute respiratory distress syndrome mouse models [99]. Furthermore, the M2 macrophages educated by MSC-EVs promoted wound healing in the injured tendons in a mouse Achilles tendon rupture model [100]. It was similarly observed that MSC-EVs augmented an anti-inflammatory M2 macrophages and resulted in alleviation of hyperoxia-induced bronchopulmonary dysplasia (BPD), improvement of lung function, decrease in fibrosis and pulmonary vascular remodeling, and amelioration of pulmonary hypertension [101]. MSC-EVs accelerated tissue repair as well in cardiotoxin-induced skeletal muscle injury model through inducing macrophage M2-like phenotype polarization [102]. In addition to inducing phenotypic changes, MSC-EVs downregulate the levels of inflammatory cytokines (IL-22 and IL-23) and substantially increase the expression of the anti-inflammatory molecule PGE2 [103]. Additionally, it has been demonstrated 
that MSC-EVs attenuate antigen uptake by immature DCs and reduce DC maturation with decreased expression of CD83 and production of IL-12. Subsequently, T cells stimulated with MSC-EV-treated DCs exhibit reduced secretion of IFN-y and IL-6 [104]. A group showed that direct treatment with MSC-EVs induced $\mathrm{T}$ cell apoptosis without significantly suppressing cell proliferation; however, MSC-EVs strongly induced Treg proliferation and increased the expression of the anti-inflammatory cytokine IL-10 [105]. The same group also investigated the immunosuppressive effects of MSC-EVs on B cells. It was found that MSC-EVs could reproduce the inhibition of B cell proliferation and differentiation in a CpG-stimulated peripheral blood mononuclear cell coculture system in a dose-dependent manner [106]. In addition, several studies have reported that MSC-EVs induce Treg development in vivo in disease models. For instance, EVs derived from human embryonic stem cell-MSCs could induce the generation of Tregs in allogeneic skin graft models [107]. EVs from BM-MSCs suppress the immune reaction by inhibiting PBMC proliferation and enhancing Treg function, hence improving islet transplantation [108]. MSC-EVs increase the number of Tregs and levels of TGFb and HGF involved in liver regeneration in a concanavalin A-induced liver injury model [109]. Moreover, exosomes have been compared to microvesicles with variable results. Only the exosome-rich fraction induced an improvement of renal function and morphology in an acute kidney injury model, whereas the best formulation to reduce radiation damage to BM-MSCs included both types of EVs [110,111]. Compared to MSCs, cell-free EVs have fewer concerns regarding immunogenicity, tumorigenicity, storage and handling procedures, and embolism formation after administration. In particular, it is relatively easy to modify EVs to improve the effective contents and surface availability to enhance therapeutic benefits. Based on these advantages, MSC-EVs hold promising potential as novel treatments that represent an alternative to stem cell therapy.

\section{Clinical Application of the Immunomodulation Mediated by MSCs}

Further investigation and understanding of the immunomodulatory effects of MSCs have provided novel insights into the treatment of immune-mediated diseases. A variety of immune disorder diseases, including graft-versus-host disease (GVHD), Crohn's disease, multiple sclerosis (MS), SLE and diabetes, have entered clinical trials of MSC therapies (Table 1).

Table 1. Summary of the clinical application of MSCs.

\begin{tabular}{|c|c|c|c|c|c|c|}
\hline Disease & Sample Size & Study Period & Origin & Dosage & Injection & Reference \\
\hline aGVHD & 1 & 1 year & allogeneic BM MSCs & $1,2 \times 10^{6} / \mathrm{kg}$ & i.v. & [112] \\
\hline aGVHD & 55 & 60 months & allogeneic BM MSCs & $1.4 \times 10^{6} / \mathrm{kg}$ & i.v. & [113] \\
\hline aGVHD & 12 & 427-1111 days & allogeneic BM MSCs & $\begin{array}{l}8 \times 10^{6} / \mathrm{kg} \\
2 \times 10^{6} / \mathrm{kg}\end{array}$ & i.v. & [114] \\
\hline aGVHD & 75 & 2-1639 days & allogeneic BM MSCs & $2 \times 10^{6} / \mathrm{kg}$ & i.v. & [115] \\
\hline aGVHD & 13 & 55-692 days & allogeneic BM MSCs & $0.9 \times 10^{6} / \mathrm{kg}$ & i.v. & [116] \\
\hline GVHD & 11 & 4-18 months & allogeneic BM MSCs & $1.2 \times 10^{6} / \mathrm{kg}$ & i.v. & [117] \\
\hline CD & 12 & 1 year & autogenous BM MSCs & $2 \times 10^{7} / \mathrm{kg}$ & $\begin{array}{l}\text { Lumen and the } \\
\text { walls of the tracks }\end{array}$ & [118] \\
\hline $\mathrm{CD}$ & 16 & 6 weeks & allogeneic MSCs & $2 \times 10^{6} / \mathrm{kg}$ & i.v. & [119] \\
\hline $\mathrm{CD}$ & 12 & 2 years & human placenta-MSCs & $2,5,10 \times 10^{6} / \mathrm{kg}$ & i.v. & [120] \\
\hline MS & 10 & 13-26 months & autogenous BM MSCs & $8.73 \times 10^{6} /$ person & Intrathecally & [121] \\
\hline MS & 10 & 1 year & autogenous BM MSCs & $3-5 \times 10^{7} /$ person & $\begin{array}{c}\text { The subarachnoid } \\
\text { space }\end{array}$ & [122] \\
\hline MS & 10 & 20 months & autogenous BM MSCs & $1.6 \times 10^{6} / \mathrm{kg}$ & i.v. & [123] \\
\hline T1D & 2 & 1 year & autogenous BM MSCs & $180 \times 10^{6} / \mathrm{kg}$ & Liver puncture & [124] \\
\hline T1D & 20 & 1 year & autogenous BM MSCs & $2.75 \times 10^{6} / \mathrm{kg}$ & i.v. & [125] \\
\hline $\mathrm{AD}$ & 34 & 1,3 months & human UCB MSCs & $2.5,5 \times 10^{7} / \mathrm{kg}$ & Subcutaneously & [126] \\
\hline
\end{tabular}

aGVHD, acute graft versus host disease; CD, Crohn's disease; MS: Multiple sclerosis; T1D: type 1 diabetes; AD: atopic dermatitis; i.v.: intravenously; BM MSCs: MSCs derived from bone marrow; UCB MSCs: MSCs derived from umbilical cord blood. 


\subsection{Graft-Versus-Host Disease (GVHD)}

GVHD continues to be the main barrier that limits the wider application of allogeneic hematopoietic cell transplantation (HCT) [127]. The first successful case of MSC treatment for GVHD reported BM-MSCs transplanted into a patient with severe grade IV acute GVHD in the gut and liver [112]. The patient received two rounds of transplantation, and patient lymphocyte proliferation was inhibited by $90 \%$. This clinical trial encouraged prospective studies with MSCs for GVHD treatment $[113,114]$. Another clinical study enrolled 75 patients and reported that the overall response rate at day +28 was $61.3 \%$, and this response was correlated with significantly improved survival at day +100 after MSC infusion [115]. However, some studies have shown inconsistent results regarding efficiency and safety. In one study, only two patients (15\%) responded, and another 11 patients required further escalation of immunosuppressive therapy when the median dose of MSC cells was $2 \times 10^{6} / \mathrm{kg}$ (range 1-5). Although a follow-up study supported the efficacy of MSCs in the treatment of steroid-refractory acute GVHD, the response to MSC transfusion was lower than that in previous cases [116]. Similarly, in a study of 11 patients who received intravenous MSCs for GVHD at a median dose of $1.2 \times 10^{6} / \mathrm{kg}$ (range 0.7-3.7), only four patients achieved a complete response initially, while four patients presented GVHD recurrence between two and five months, and two patients developed chronic limited GVHD [117]. The dose of MSCs used in current clinical trials ranges from $1 \times 10^{6}$ to $2 \times 10^{8}$ cells $/ \mathrm{kg}$, and the number of administrations varies from one to eight [128]. The inconsistent outcomes might result from variation in the translation from preclinical studies to clinical application, including the homogeneity of the MSCs, the optimal dose and frequency of administration, and the complicated physical conditions of the patients.

\subsection{Crohn's Disease}

Crohn's disease (CD) is a chronic inflammatory bowel disease characterized by inflammation in the digestive or gastrointestinal tract. A study showed that a local injection of autologous MSCs increased mucosal and circulating Treg frequencies in patients with CD [118]. Subsequently, the continuation of the study reported the outcome of a five-year follow-up study of the phase 2 trial. Disease remission was observed 12 months after MSC infusion, and the mean CD activity index (CDAI) score increased significantly, followed by a gradual decrease with eventual remission achieved at the end of the five-year follow-up period. The probability of fistula relapse-free survival was $88 \%$ at one year but decreased to 37\% during the following four years [129]. A phase 2 study included 16 patients who received intravenous infusions of allogeneic MSCs $\left(2 \times 10^{6} / \mathrm{kg}\right)$ weekly for four weeks and showed decreased CDAI scores after each MSC infusion. Twelve of 15 patients had a clinical response, and eight achieved clinical remission [119]. A phase 1 trial also proved the feasibility and safety of autologous BM-MSC therapy for CD. Twelve patients received a single MSC intravenous injection of 2, 5 or $10 \times 10^{6}$ cells $/ \mathrm{kg}$, and all patients tolerated the infusion well [120].

\subsection{Multiple Sclerosis}

Multiple sclerosis (MS) is a demyelinating and chronic inflammatory disease of the central nervous system [130]. It was first reported that 10 patients with progressive-type MS received autologous MSC transplantation in 2007. After MSC treatment, they did not experience any major adverse events, and during 13 to 26 months of follow up, the expended disability status scale (EDSS) score of one patient improved from 5 to 2.5 , the scores of five patients increased from 0.5 to 2.5 , and the scores of four patients showed no change. This research confirmed the feasibility of using autologous MSCs for the treatment of MS patients [121]. Subsequently, a pilot study investigated the safety and therapeutic benefits of autologous BM-MSCs in primary progressive MS patients. MSCs were infused into the subarachnoid space at the C1-C2 and L2-L3 disc space levels. Over the next six months, EDSS scores improved by $0.5-1.0$ in five of seven patients, remained unchanged in one patient, and worsened by 0.5 in one patient. The overall attrition rate was $30 \%$, and brain MRI showed no new 
or gadolinium-enhancing lesions in any patient [122]. These results reconfirmed the efficacy of MSC treatment for MS. In addition, a phase 2 study reported that MSC infusion produced improvements in patients with secondary progressive disease, particularly in measures of visual function, physiology, and structure, without significant adverse events [123]. The precise mechanism of MSC-mediated immunomodulation in MS is not known and requires further exploration.

\subsection{Other Immune-Related Diseases}

Since MSCs were found to be able to differentiate into insulin-producing cells, MSC therapy has emerged as a promising approach for diabetes. It was reported that MSC injection via liver puncture in two patients with type 1 diabetes reduced the expression levels of islet cell antibody (ICA), glutamic acid decarboxylase (GAD) and anti-insulin antibodies, and increased the level of C-peptide [124]. In addition, systemic MSC treatment at a mean dose of $2.75 \times 10^{6} \mathrm{cells} / \mathrm{kg}$ via intravenous administration could improve the C-peptide response in patients with type 1 diabetes [125]. Based on the therapeutic effects of MSCs on atopic dermatitis (AD) in preclinical studies, the safety and efficacy of MSCs in clinical application has been investigated. Thirty-four patients with moderate-to-severe AD received subcutaneous injection of hUCB-MSCs at a dose of $2.5 \times 10^{7}$ or $5 \times 10^{7} / \mathrm{kg}$ and subsequently rapidly improved without adverse events. The case report suggested that efficacy was dependent on the dose and frequency of injection of hUCB-MSCs [126]. Actually, it is difficult to assess the benefits of MSC therapy by comparing the results of published studies because of the small number of patients involved in most clinical trials and various different approaches in regard to MSC sources, preparation, administration and efficacy, and safety tests (Table 2). In addition, the implied possible complications of MSC cell therapy are associated with the immunosuppressive properties of MSCs due to the reduction in the immunosurveillance of host neoantigens and foreign pathogens or viruses [131]. In addition, autologous MSCs may induce tumors by promoting tumor cell growth, whereas allogeneic MSCs derived from donors may increase infectious risk. Secreted factors or conditioned medium may offer advantages over cell-based therapy because of the more specific contents and definite signaling pathways involved, thereby producing the expected clinical outcome. Thus, the paracrine function of MSCs provides the possibility of applying a specific factor alone or in combination as a cocktail therapy for treatment.

Table 2. The challenges in clinical application of MSC therapy.

\begin{tabular}{ll}
\hline Problems & Detailed Questions \\
\hline Origin of MSCs & Currently commonly used: bone marrow, adipose tissue, umbilical cord \\
& Other choices remain to be explored: dental pulp, thymus, gingiva, saphenous vein, \\
& fetal tissues \\
& Age of donors \\
Ex-vivo preparation & Ex-vivo culture conditions \\
& Specific genetic modification \\
& Cell dose and frequency \\
Protocols of injection & Transfusion way \\
& Combined with chemotherapy \\
& Efficacy test \\
& Safety test \\
Assessment & Follow-up study \\
\end{tabular}

\section{Conclusions}

MSCs have emerged as a promising candidate for therapeutic application due to their multidifferentiation potential and immunomodulatory properties. In addition to performing functions via cell-cell contact, MSCs exert immunoregulatory functions through the combined reactions of chemokines, cytokines, and extracellular vesicles secreted by MSCs, as well as the microenvironment and inflammatory stimuli. Surprisingly, although the immunomodulatory capacities of MSCs have 
only recently been confirmed, MSC therapies are of great interest and widely explored, and approval has been obtained for clinical trials treating inflammatory or autoimmune diseases in the United States, Europe, and China. Accumulating clinical studies have demonstrated the excellent therapeutic benefits of MSC therapy for the treatment of several immune diseases due to the immunomodulatory function of MSCs. However, the risks of MSC therapy include immunosuppression, ectopic differentiation and tumor growth promotion. Paracrine-based, cell-free therapy holds great promise as a controllable, manageable, and feasible alternative. We believe that further investigation of the molecular mechanisms and signaling networks that regulate paracrine activities will promote the clinical application from bench to bedside in the near future.

Author Contributions: Y.Z. searched for information and wrote the paper. Y.Y., T.O. and Z.X. reviewed and edited the manuscript. All authors read and approved the manuscript.

Funding: This work was supported by Project for Cancer Research and Therapeutic Evolution (P-CREATE; grant number: 17cm0106402h0002), MEXT KAKENHI (Grant-in-Aid for Young Scientists (A); grant number: 17H04991) and China Scholarship Council (grant number: 201706090122).

Conflicts of Interest: The authors declare no conflict of interest.

\section{References}

1. Friedenstein, A.J.; Chailakhjan, R.K.; Lalykina, K.S. The Development of Fibroblast Colonies in Monolayer Cultures of Guinea-Pig Bone Marrow and Spleen Cells. Cell Prolif. 1970, 3, 393-403. [CrossRef]

2. Mcelreavey, K.D.; Irvine, A.I.; Ennis, K.T.; Mclean, W.H.I. Isolation, culture and characterisation of fibroblast-like cells derived from the Wharton's jelly portion of human umbilical cord. Biochem. Soc. Trans. 1991, 19, 29S. [CrossRef] [PubMed]

3. Noort, W.; Scherjon, S.; Kleijburg-van der Keur, C.; Kruisselbrink, A.; van Bezooijen, R.; Beekhuizen, W.; Willemze, R.; Kanhai, H.; Fibbe, W. Mesenchymal stem cells in human second-trimester bone marrow, liver, lung, and spleen exhibit a similar immunophenotype but a heterogeneous multilineage differentiation potential. Haematologica 2003, 88, 845-852.

4. Gruber, H.E.; Deepe, R.; Hoelscher, G.L.; Ingram, J.A.; Norton, H.J.; Scannell, B.; Loeffler, B.J.; Zinchenko, N.; Hanley, E.N.; Tapp, H. Human Adipose-Derived Mesenchymal Stem Cells: Direction to a Phenotype Sharing Similarities with the Disc, Gene Expression Profiling, and Coculture with Human Annulus Cells. Tissue Eng. Part A 2010, 16, 2843-2860. [CrossRef] [PubMed]

5. Ponnaiyan, D.; Bhat, K.M.; Bhat, G.S. Comparison of Immuno-Phenotypes of Stem Cells from Human Dental Pulp and Periodontal Ligament. Int. J. Immunopathol. Pharmacol. 2012, 25, 127-134. [CrossRef] [PubMed]

6. HORWITZ, E.M.; Blanc, K.L.; Dominici, M. Clarification of the nomenclature for MSC: The International Society for Cellular Therapy position statement. Cytotherapy 2005, 7, 393-395. [CrossRef] [PubMed]

7. Pittenger, M.F.; Mackay, A.M.; Beck, S.C.; Jaiswal, R.K.; Douglas, R.; Mosca, J.D.; Moorman, M.A.; Simonetti, D.W.; Craig, S.; Marshak, D.R. Multilineage Potential of Adult Human Mesenchymal Stem Cells. Science 1999, 284, 143-147. [CrossRef]

8. Krebsbach, P.H.; Kuznetsov, S.A.; Bianco, P.; Gehron Robey, P. Bone Marrow Stromal Cells: Characterization and Clinical Application. Crit. Rev. Oral Biol. Med. 1999, 10, 165-181. [CrossRef]

9. da Silva Meirelles, S.; Chagastelles, P.C.; Nardi, N.B. Mesenchymal stem cells reside in virtually all post-natal organs and tissues. J. Cell Sci. 2006, 119, 2204-2213. [CrossRef]

10. Arthur, A.; Zannettino, A.; Gronthos, S. The therapeutic applications of multipotential mesenchymal/stromal stem cells in skeletal tissue repair. J. Cell. Physiol. 2009, 218, 237-245. [CrossRef]

11. Asanuma, H.; Meldrum, D.R.; Meldrum, K.K. Therapeutic Applications of Mesenchymal Stem Cells to Repair Kidney Injury. J. Urol. 2010, 184, 26-33. [CrossRef] [PubMed]

12. Liang, X.; Ding, Y.; Zhang, Y.; Tse, H.-F.; Lian, Q. Paracrine Mechanisms of Mesenchymal Stem Cell-Based Therapy: Current Status and Perspectives. Cell Transplant. 2014, 23, 1045-1059. [CrossRef]

13. Corcione, A.; Benvenuto, F.; Ferretti, E.; Giunti, D.; Cappiello, V.; Cazzanti, F.; Risso, M.; Gualandi, F.; Mancardi, G.L.; Pistoia, V.; et al. Human mesenchymal stem cells modulate B-cell functions. Blood 2006, 107, 367-372. [CrossRef] [PubMed] 
14. Castro-Manrreza, M.E.; Montesinos, J.J. Immunoregulation by mesenchymal stem cells: Biological aspects and clinical applications. J. Immunol. Res. 2015, 2015, 394917. [CrossRef] [PubMed]

15. Murphy, M.B.; Moncivais, K.; Caplan, A.I. Mesenchymal stem cells: Environmentally responsive therapeutics for regenerative medicine. Exp. Mol. Med. 2013, 45, e54. [CrossRef]

16. Caplan, A.I. MSCs: The Sentinel and Safe-Guards of Injury. J. Cell. Physiol. 2016, 231, 1413-1416. [CrossRef] [PubMed]

17. Kern, S.; Eichler, H.; Stoeve, J.; Klüter, H.; Bieback, K. Comparative Analysis of Mesenchymal Stem Cells from Bone Marrow, Umbilical Cord Blood, or Adipose Tissue. Stem Cells 2006, 24, 1294-1301. [CrossRef]

18. Amable, P.R.; Teixeira, M.V.T.; Carias, R.B.V.; Granjeiro, J.M.; Borojevic, R. Protein synthesis and secretion in human mesenchymal cells derived from bone marrow, adipose tissue and Wharton's jelly. Stem Cell Res. Ther. 2014, 5, 53. [CrossRef]

19. Gnecchi, M.; He, H.; Liang, O.D.; Melo, L.G.; Morello, F.; Mu, H.; Noiseux, N.; Zhang, L.; Pratt, R.E.; Ingwall, J.S.; et al. Paracrine action accounts for marked protection of ischemic heart by Akt-modified mesenchymal stem cells. Nat. Med. 2005, 11, 367. [CrossRef]

20. Lin, H.-T.; Otsu, M.; Nakauchi, H. Stem cell therapy: An exercise in patience and prudence. Philos. Trans. R. Soc. B Biol. Sci. 2013, 368, 20110334. [CrossRef]

21. Najar, M.; Bouhtit, F.; Melki, R.; Afif, H.; Hamal, A.; Fahmi, H.; Merimi, M.; Lagneaux, L. Mesenchymal Stromal Cell-Based Therapy: New Perspectives and Challenges. J. Clin. Med. 2019, 8, 626. [CrossRef] [PubMed]

22. Yip, H.-K.; Lee, M.S.; Sun, C.-K.; Chen, K.-H.; Chai, H.-T.; Sung, P.-H.; Lin, K.-C.; Ko, S.-F.; Yuen, C.-M.; Liu, C.-F.; et al. Therapeutic effects of adipose-derived mesenchymal stem cells against brain death-induced remote organ damage and post-heart transplant acute rejection. Oncotarget 2017, 8, 108692-108711. [CrossRef] [PubMed]

23. Ringdén, O.; Uzunel, M.; Rasmusson, I.; Remberger, M.; Sundberg, B.; Lönnies, H.; Marschall, H.-U.; Dlugosz, A.; Szakos, A.; Hassan, Z.; et al. Mesenchymal Stem Cells for Treatment of Therapy-Resistant Graft-versus-Host Disease. Transplantation 2006, 81, 1390-1397. [CrossRef] [PubMed]

24. Kopen, G.C.; Prockop, D.J.; Phinney, D.G. Marrow stromal cells migrate throughout forebrain and cerebellum, and they differentiate into astrocytes after injection into neonatal mouse brains. Proc. Natl. Acad. Sci. USA 1999, 96, 10711-10716. [CrossRef] [PubMed]

25. Meier, R.P.H.; Müller, Y.D.; Morel, P.; Gonelle-Gispert, C.; Bühler, L.H. Transplantation of mesenchymal stem cells for the treatment of liver diseases, is there enough evidence? Stem Cell Res. 2013, 11, 1348-1364. [CrossRef]

26. Matthay, M.A.; Goolaerts, A.; Howard, J.P.; Lee, J.W. Mesenchymal stem cells for acute lung injury: Preclinical evidence. Crit. Care Med. 2010, 38, S569-S573. [CrossRef] [PubMed]

27. Bhansali, A.; Upreti, V.; Khandelwal, N.; Marwaha, N.; Gupta, V.; Sachdeva, N.; Sharma, R.R.; Saluja, K.; Dutta, P.; Walia, R.; et al. Efficacy of Autologous Bone Marrow-Derived Stem Cell Transplantation in Patients with Type 2 Diabetes Mellitus. Stem Cells Dev. 2009, 18, 1407-1416. [CrossRef]

28. Yan, X.; Cen, Y.; Wang, Q. Mesenchymal stem cells alleviate experimental rheumatoid arthritis through microRNA-regulated IкB expression. Sci. Rep. 2016, 6, 28915. [CrossRef]

29. Teixeira, F.G.; Panchalingam, K.M.; Assunção-Silva, R.; Serra, S.C.; Mendes-Pinheiro, B.; Patrício, P.; Jung, S.; Anjo, S.I.; Manadas, B.; Pinto, L.; et al. Modulation of the Mesenchymal Stem Cell Secretome Using Computer-Controlled Bioreactors: Impact on Neuronal Cell Proliferation, Survival and Differentiation. Sci. Rep. 2016, 6, 27791. [CrossRef]

30. Heathman, T.R.J.; Rafiq, Q.A.; Chan, A.K.C.; Coopman, K.; Nienow, A.W.; Kara, B.; Hewitt, C.J. Characterization of human mesenchymal stem cells from multiple donors and the implications for large scale bioprocess development. Scale-Manuf. Cell-Based Ther. IV 2016, 108, 14-23. [CrossRef]

31. Orlic, D.; Kajstura, J.; Chimenti, S.; Jakoniuk, I.; Anderson, S.M.; Li, B.; Pickel, J.; McKay, R.; Nadal-Ginard, B.; Bodine, D.M.; et al. Bone marrow cells regenerate infarcted myocardium. Nature 2001, 410, 701-705. [CrossRef] [PubMed]

32. Strauer, B.E.; Brehm, M.; Zeus, T.; Köstering, M.; Hernandez, A.; Sorg, R.V.; Kögler, G.; Wernet, P. Repair of Infarcted Myocardium by Autologous Intracoronary Mononuclear Bone Marrow Cell Transplantation in Humans. Circulation 2002, 106, 1913-1918. [CrossRef] 
33. Assmus, B.; Schächinger, V.; Teupe, C.; Britten, M.; Lehmann, R.; Döbert, N.; Grünwald, F.; Aicher, A.; Urbich, C.; Martin, H.; et al. Transplantation of Progenitor Cells and Regeneration Enhancement in Acute Myocardial Infarction (TOPCARE-AMI). Circulation 2002, 106, 3009-3017. [CrossRef] [PubMed]

34. Tögel, F.; Hu, Z.; Weiss, K.; Isaac, J.; Lange, C.; Westenfelder, C. Administered mesenchymal stem cells protect against ischemic acute renal failure through differentiation-independent mechanisms. Am. J. Physiol.-Ren. Physiol. 2005, 289, F31-F42. [CrossRef]

35. Takahashi, M.; Li, T.-S.; Suzuki, R.; Kobayashi, T.; Ito, H.; Ikeda, Y.; Matsuzaki, M.; Hamano, K. Cytokines produced by bone marrow cells can contribute to functional improvement of the infarcted heart by protecting cardiomyocytes from ischemic injury. Am. J. Physiol.-Heart Circ. Physiol. 2006, 291, H886-H893. [CrossRef] [PubMed]

36. Leiker, M.; Suzuki, G.; Iyer, V.S.; Canty, J.M., Jr.; Lee, T. Assessment of a nuclear affinity labeling method for tracking implanted mesenchymal stem cells. Cell Transplant. 2008, 17, 911-922. [CrossRef]

37. Murry, C.E.; Soonpaa, M.H.; Reinecke, H.; Nakajima, H.; Nakajima, H.O.; Rubart, M.; Pasumarthi, K.B.S.; Ismail Virag, J.; Bartelmez, S.H.; Poppa, V.; et al. Haematopoietic stem cells do not transdifferentiate into cardiac myocytes in myocardial infarcts. Nature 2004, 428, 664-668. [CrossRef]

38. Gnecchi, M.; He, H.; Noiseux, N.; Liang, O.D.; Zhang, L.; Morello, F.; Mu, H.; Melo, L.G.; Pratt, R.E.; Ingwall, J.S.; et al. Evidence supporting paracrine hypothesis for Akt-modified mesenchymal stem cell-mediated cardiac protection and functional improvement. FASEB J. 2006, 20, 661-669. [CrossRef]

39. Lee, R.H.; Pulin, A.A.; Seo, M.J.; Kota, D.J.; Ylostalo, J.; Larson, B.L.; Semprun-Prieto, L.; Delafontaine, P.; Prockop, D.J. Intravenous hMSCs Improve Myocardial Infarction in Mice because Cells Embolized in Lung Are Activated to Secrete the Anti-inflammatory Protein TSG-6. Cell Stem Cell 2009, 5, 54-63. [CrossRef]

40. Shabbir, A.; Zisa, D.; Suzuki, G.; Lee, T. Heart failure therapy mediated by the trophic activities of bone marrow mesenchymal stem cells: A noninvasive therapeutic regimen. Am. J. Physiol. Heart Circ. Physiol. 2009, 296, H1888-H1897. [CrossRef]

41. Nakamura, Y.; Miyaki, S.; Ishitobi, H.; Matsuyama, S.; Nakasa, T.; Kamei, N.; Akimoto, T.; Higashi, Y.; Ochi, M. Mesenchymal-stem-cell-derived exosomes accelerate skeletal muscle regeneration. FEBS Lett. 2015, 589, 1257-1265. [CrossRef] [PubMed]

42. Shao, L.; Zhang, Y.; Lan, B.; Wang, J.; Zhang, Z.; Zhang, L.; Xiao, P.; Meng, Q.; Geng, Y.-J.; Yu, X.-Y.; et al. MiRNA-Sequence Indicates That Mesenchymal Stem Cells and Exosomes Have Similar Mechanism to Enhance Cardiac Repair. BioMed Res. Int. 2017, 2017, 4150705. [CrossRef] [PubMed]

43. Juneja, H.S.; Rajaraman, S.; Ramsey, K.M.; Elder, F.F.B. Role of marrow stromal cells in the establishment of a transformed lymphoblastic B-cell line from a normal human subject. Leuk. Res. 1986, 10, 1209-1219. [CrossRef]

44. Cselenyák, A.; Pankotai, E.; Horváth, E.M.; Kiss, L.; Lacza, Z. Mesenchymal stem cells rescue cardiomyoblasts from cell death in an in vitro ischemia model via direct cell-to-cell connections. BMC Cell Biol. 2010, 11, 29. [CrossRef] [PubMed]

45. Gatti, S.; Bruno, S.; Deregibus, M.C.; Sordi, A.; Cantaluppi, V.; Tetta, C.; Camussi, G. Microvesicles derived from human adult mesenchymal stem cells protect against ischaemia-reperfusion-induced acute and chronic kidney injury. Nephrol. Dial. Transplant. 2011, 26, 1474-1483. [CrossRef] [PubMed]

46. Islam, M.N.; Das, S.R.; Emin, M.T.; Wei, M.; Sun, L.; Westphalen, K.; Rowlands, D.J.; Quadri, S.K.; Bhattacharya, S.; Bhattacharya, J. Mitochondrial transfer from bone-marrow-derived stromal cells to pulmonary alveoli protects against acute lung injury. Nat. Med. 2012, 18, 759. [CrossRef] [PubMed]

47. Di Nicola, M.; Carlo-Stella, C.; Magni, M.; Milanesi, M.; Longoni, P.D.; Matteucci, P.; Grisanti, S.; Gianni, A.M. Human bone marrow stromal cells suppress T-lymphocyte proliferation induced by cellular or nonspecific mitogenic stimuli. Blood 2002, 99, 3838-3843. [CrossRef] [PubMed]

48. Unanue, E.R. Antigen-Presenting Function of the Macrophage. Annu. Rev. Immunol. 1984, 2, $395-428$. [CrossRef]

49. Murray, P.J.; Wynn, T.A. Protective and pathogenic functions of macrophage subsets. Nat. Rev. Immunol. 2011, 11, 723. [CrossRef]

50. Wynn, T.A.; Chawla, A.; Pollard, J.W. Macrophage biology in development, homeostasis and disease. Nature 2013, 496, 445. [CrossRef] 
51. Németh, K.; Leelahavanichkul, A.; Yuen, P.S.T.; Mayer, B.; Parmelee, A.; Doi, K.; Robey, P.G.; Leelahavanichkul, K.; Koller, B.H.; Brown, J.M.; et al. Bone marrow stromal cells attenuate sepsis via prostaglandin E2-dependent reprogramming of host macrophages to increase their interleukin-10 production. Nat. Med. 2008, 15, 42. [CrossRef] [PubMed]

52. Ren, G.; Zhao, X.; Wang, Y.; Zhang, X.; Chen, X.; Xu, C.; Yuan, Z.; Roberts, A.I.; Zhang, L.; Zheng, B.; et al. CCR2-Dependent Recruitment of Macrophages by Tumor-Educated Mesenchymal Stromal Cells Promotes Tumor Development and Is Mimicked by TNF $\alpha$. Cell Stem Cell 2012, 11, 812-824. [CrossRef] [PubMed]

53. Cao, X.; Han, Z.-B.; Zhao, H.; Liu, Q. Transplantation of mesenchymal stem cells recruits trophic macrophages to induce pancreatic beta cell regeneration in diabetic mice. Int. J. Biochem. Cell Biol. 2014, 53, 372-379. [CrossRef] [PubMed]

54. Abumaree, M.H.; Al Jumah, M.A.; Kalionis, B.; Jawdat, D.; Al Khaldi, A.; Abomaray, F.M.; Fatani, A.S.; Chamley, L.W.; Knawy, B.A. Human Placental Mesenchymal Stem Cells (pMSCs) Play a Role as Immune Suppressive Cells by Shifting Macrophage Differentiation from Inflammatory M1 to Anti-inflammatory M2 Macrophages. Stem Cell Rev. Rep. 2013, 9, 620-641. [CrossRef] [PubMed]

55. Zhang, W.; Ge, W.; Li, C.; You, S.; Liao, L.; Han, Q.; Deng, W.; Zhao, R.C.H. Effects of Mesenchymal Stem Cells on Differentiation, Maturation, and Function of Human Monocyte-Derived Dendritic Cells. Stem Cells Dev. 2004, 13, 263-271. [CrossRef] [PubMed]

56. Nauta, A.J.; Kruisselbrink, A.B.; Lurvink, E.; Willemze, R.; Fibbe, W.E. Mesenchymal Stem Cells Inhibit Generation and Function of Both CD34 ${ }^{+}$-Derived and Monocyte-Derived Dendritic Cells. J. Immunol. 2006, 177, 2080-2087. [CrossRef] [PubMed]

57. Djouad, F.; Charbonnier, L.-M.; Bouffi, C.; Louis-Plence, P.; Bony, C.; Apparailly, F.; Cantos, C.; Jorgensen, C.; Noël, D. Mesenchymal Stem Cells Inhibit the Differentiation of Dendritic Cells Through an Interleukin-6-Dependent Mechanism. Stem Cells 2007, 25, 2025-2032. [CrossRef]

58. Liu, Y.; Yin, Z.; Zhang, R.; Yan, K.; Chen, L.; Chen, F.; Huang, W.; Lv, B.; Sun, C.; Jiang, X. MSCs inhibit bone marrow-derived DC maturation and function through the release of TSG-6. Biochem. Biophys. Res. Commun. 2014, 450, 1409-1415. [CrossRef]

59. English, K.; Barry, F.P.; Mahon, B.P. Murine mesenchymal stem cells suppress dendritic cell migration, maturation and antigen presentation. Immunol. Lett. 2008, 115, 50-58. [CrossRef]

60. Chiesa, S.; Morbelli, S.; Morando, S.; Massollo, M.; Marini, C.; Bertoni, A.; Frassoni, F.; Bartolomé, S.T.; Sambuceti, G.; Traggiai, E.; et al. Mesenchymal stem cells impair in vivo T-cell priming by dendritic cells. Proc. Natl. Acad. Sci. USA 2011, 108, 17384-17389. [CrossRef]

61. Mantovani, A.; Cassatella, M.A.; Costantini, C.; Jaillon, S. Neutrophils in the activation and regulation of innate and adaptive immunity. Nat. Rev. Immunol. 2011, 11, 519. [CrossRef] [PubMed]

62. Raffaghello, L.; Bianchi, G.; Bertolotto, M.; Montecucco, F.; Busca, A.; Dallegri, F.; Ottonello, L.; Pistoia, V. Human Mesenchymal Stem Cells Inhibit Neutrophil Apoptosis: A Model for Neutrophil Preservation in the Bone Marrow Niche. Stem Cells 2008, 26, 151-162. [CrossRef]

63. Yu, P.F.; Huang, Y.; Han, Y.Y.; Lin, L.Y.; Sun, W.H.; Rabson, A.B.; Wang, Y.; Shi, Y.F. TNF $\alpha$-activated mesenchymal stromal cells promote breast cancer metastasis by recruiting CXCR2+ neutrophils. Oncogene 2016, 36, 482. [CrossRef] [PubMed]

64. Brandau, S.; Jakob, M.; Bruderek, K.; Bootz, F.; Giebel, B.; Radtke, S.; Mauel, K.; Jäger, M.; Flohé, S.B.; Lang, S. Mesenchymal Stem Cells Augment the Anti-Bacterial Activity of Neutrophil Granulocytes. PLoS ONE 2014, 9, e106903. [CrossRef] [PubMed]

65. Jiang, D.; Muschhammer, J.; Qi, Y.; Kügler, A.; de Vries, J.C.; Saffarzadeh, M.; Sindrilaru, A.; Beken, S.V.; Wlaschek, M.; Kluth, M.A.; et al. Suppression of Neutrophil-Mediated Tissue Damage-A Novel Skill of Mesenchymal Stem Cells. Stem Cells 2016, 34, 2393-2406. [CrossRef] [PubMed]

66. Björkström, N.K.; Ljunggren, H.-G.; Michaëlsson, J. Emerging insights into natural killer cells in human peripheral tissues. Nat. Rev. Immunol. 2016, 16, 310. [CrossRef] [PubMed]

67. Spaggiari, G.M.; Capobianco, A.; Becchetti, S.; Mingari, M.C.; Moretta, L. Mesenchymal stem cell-natural killer cell interactions: Evidence that activated NK cells are capable of killing MSCs, whereas MSCs can inhibit IL-2-induced NK-cell proliferation. Blood 2006, 107, 1484-1490. [CrossRef] [PubMed]

68. Sotiropoulou, P.A.; Perez, S.A.; Gritzapis, A.D.; Baxevanis, C.N.; Papamichail, M. Interactions Between Human Mesenchymal Stem Cells and Natural Killer Cells. Stem Cells 2006, 24, 74-85. [CrossRef] 
69. Spaggiari, G.M.; Capobianco, A.; Abdelrazik, H.; Becchetti, F.; Mingari, M.C.; Moretta, L. Mesenchymal stem cells inhibit natural killer-cell proliferation, cytotoxicity, and cytokine production: Role of indoleamine 2,3-dioxygenase and prostaglandin E2. Blood 2008, 111, 1327-1333. [CrossRef]

70. Selmani, Z.; Naji, A.; Zidi, I.; Favier, B.; Gaiffe, E.; Obert, L.; Borg, C.; Saas, P.; Tiberghien, P.; Rouas-Freiss, N.; et al. Human Leukocyte Antigen-G5 Secretion by Human Mesenchymal Stem Cells Is Required to Suppress T Lymphocyte and Natural Killer Function and to Induce CD4+CD25highFOXP3+ Regulatory T Cells. Stem Cells 2008, 26, 212-222. [CrossRef]

71. Thomas, H.; Jäger, M.; Mauel, K.; Brandau, S.; Lask, S.; Flohé, S.B. Interaction with mesenchymal stem cells provokes natural killer cells for enhanced IL-12/IL-18-induced interferon-gamma secretion. Mediators Inflamm. 2014, 2014, 143463. [CrossRef] [PubMed]

72. Boissel, L.; Tuncer, H.H.; Betancur, M.; Wolfberg, A.; Klingemann, H. Umbilical Cord Mesenchymal Stem Cells Increase Expansion of Cord Blood Natural Killer Cells. Biol. Blood Marrow Transplant. 2008, 14, 1031-1038. [CrossRef] [PubMed]

73. Janeway, C.J.; Travers, P.; Walport, M. T cell-mediated cytotoxicity. In Immunobiology: The Immune System in Health and Disease, 5th ed.; Garland Science; Taylor \& Francis Group: New York, NY, USA, 2008.

74. Duffy, M.M.; Ritter, T.; Ceredig, R.; Griffin, M.D. Mesenchymal stem cell effects on T-cell effector pathways. Stem Cell Res. Ther. 2011, 2, 34. [CrossRef] [PubMed]

75. Meisel, R.; Zibert, A.; Laryea, M.; Göbel, U.; Däubener, W.; Dilloo, D. Human bone marrow stromal cells inhibit allogeneic T-cell responses by indoleamine 2,3-dioxygenase-mediated tryptophan degradation. Blood 2004, 103, 4619. [CrossRef] [PubMed]

76. Ryan, J.M.; Barry, F.; Murphy, J.M.; Mahon, B.P. Interferon-gamma does not break, but promotes the immunosuppressive capacity of adult human mesenchymal stem cells. Clin. Exp. Immunol. 2007, 149, 353-363. [CrossRef]

77. Aggarwal, S.; Pittenger, M.F. Human mesenchymal stem cells modulate allogeneic immune cell responses. Blood 2005, 105, 1815. [CrossRef] [PubMed]

78. Liotta, F.; Angeli, R.; Cosmi, L.; Filì, L.; Manuelli, C.; Frosali, F.; Mazzinghi, B.; Maggi, L.; Pasini, A.; Lisi, V.; et al. Toll-Like Receptors 3 and 4 Are Expressed by Human Bone Marrow-Derived Mesenchymal Stem Cells and Can Inhibit Their T-Cell Modulatory Activity by Impairing Notch Signaling. Stem Cells 2008, 26, 279-289. [CrossRef]

79. Hwa Cho, H.; Bae, Y.C.; Jung, J.S. Role of Toll-Like Receptors on Human Adipose-Derived Stromal Cells. Stem Cells 2006, 24, 2744-2752. [CrossRef]

80. Pevsner-Fischer, M.; Morad, V.; Cohen-Sfady, M.; Rousso-Noori, L.; Zanin-Zhorov, A.; Cohen, S.; Cohen, I.R.; Zipori, D. Toll-like receptors and their ligands control mesenchymal stem cell functions. Blood 2007, 109, 1422. [CrossRef]

81. English, K.; Ryan, J.M.; Tobin, L.; Murphy, M.J.; Barry, F.P.; Mahon, B.P. Cell contact, prostaglandin E(2) and transforming growth factor beta 1 play non-redundant roles in human mesenchymal stem cell induction of CD4+CD25(High) forkhead box P3+ regulatory T cells. Clin. Exp. Immunol. 2009, 156, 149-160. [CrossRef]

82. Wang, Y.; Zhang, A.; Ye, Z.; Xie, H.; Zheng, S. Bone Marrow-Derived Mesenchymal Stem Cells Inhibit Acute Rejection of Rat Liver Allografts in Association with Regulatory T-Cell Expansion. Transplant. Proc. 2009, 41, 4352-4356. [CrossRef]

83. Rafei, M.; Campeau, P.M.; Aguilar-Mahecha, A.; Buchanan, M.; Williams, P.; Birman, E.; Yuan, S.; Young, Y.K.; Boivin, M.-N.; Forner, K.; et al. Mesenchymal Stromal Cells Ameliorate Experimental Autoimmune Encephalomyelitis by Inhibiting CD4 Th17 T Cells in a CC Chemokine Ligand 2-Dependent Manner. J. Immunol. 2009, 182, 5994-6002. [CrossRef]

84. Tatara, R.; Ozaki, K.; Kikuchi, Y.; Hatanaka, K.; Oh, I.; Meguro, A.; Matsu, H.; Sato, K.; Ozawa, K. Mesenchymal stromal cells inhibit Th17 but not regulatory T-cell differentiation. Cytotherapy 2011, 13, 686-694. [CrossRef]

85. Chiossone, L.; Conte, R.; Spaggiari, G.M.; Serra, M.; Romei, C.; Bellora, F.; Becchetti, F.; Andaloro, A.; Moretta, L.; Bottino, C. Mesenchymal Stromal Cells Induce Peculiar Alternatively Activated Macrophages Capable of Dampening Both Innate and Adaptive Immune Responses. Stem Cells 2016, 34, 1909-1921. [CrossRef]

86. Liu, C.; Noorchashm, H.; Sutter, J.A.; Naji, M.; Prak, E.L.; Boyer, J.; Green, T.; Rickels, M.R.; Tomaszewski, J.E.; Koeberlein, B.; et al. B lymphocyte-directed immunotherapy promotes long-term islet allograft survival in nonhuman primates. Nat. Med. 2007, 13, 1295. [CrossRef] 
87. Franquesa, M.; Hoogduijn, M.J.; Bestard, O.; Grinyó, J.M. Immunomodulatory effect of mesenchymal stem cells on B cells. Front. Immunol. 2012, 3, 212. [CrossRef]

88. Crawford, A.; MacLeod, M.; Schumacher, T.; Corlett, L.; Gray, D. Primary T Cell Expansion and Differentiation In Vivo Requires Antigen Presentation by B Cells. J. Immunol. 2006, 176, 3498-3506. [CrossRef]

89. Ng, Y.-H.; Oberbarnscheidt, M.H.; Chandramoorthy, H.C.K.; Hoffman, R.; Chalasani, G. B cells help alloreactive T cells differentiate into memory T cells. Am. J. Transplant. 2010, 10, 1970-1980. [CrossRef]

90. Healy, M.E.; Bergin, R.; Mahon, B.P.; English, K. Mesenchymal Stromal Cells Protect Against Caspase 3-Mediated Apoptosis of CD19+ Peripheral B Cells Through Contact-Dependent Upregulation of VEGF. Stem Cells Dev. 2015, 24, 2391-2402. [CrossRef]

91. Barrio, L.; Cuevas, V.D.; Menta, R.; Mancheño-Corvo, P.; delaRosa, O.; Dalemans, W.; Lombardo, E.; Carrasco, Y.R. Human adipose tissue-derived mesenchymal stromal cells promote B-cell motility and chemoattraction. Cytotherapy 2014, 16, 1692-1699. [CrossRef]

92. Tabera, S.; Pérez-Simón, J.A.; Díez-Campelo, M.; Sánchez-Abarca, L.I.; Blanco, B.; López, A.; Benito, A.; Ocio, E.; Sánchez-Guijo, F.M.; Cañizo, C.; et al. The effect of mesenchymal stem cells on the viability, proliferation and differentiation of B-lymphocytes. Haematologica 2008, 93, 1301-1309. [CrossRef]

93. Che, N.; Li, X.; Zhang, L.; Liu, R.; Chen, H.; Gao, X.; Shi, S.; Chen, W.; Sun, L. Impaired B Cell Inhibition by Lupus Bone Marrow Mesenchymal Stem Cells Is Caused by Reduced CCL2 Expression. J. Immunol. 2014, 193, 5306-5314. [CrossRef]

94. Ji, Y.R.; Yang, Z.X.; Han, Z.-B.; Meng, L.; Liang, L.; Feng, X.M.; Yang, S.G.; Chi, Y.; Chen, D.D.; Wang, Y.W.; et al. Mesenchymal Stem Cells Support Proliferation and Terminal Differentiation of B Cells. Cell. Physiol. Biochem. 2012, 30, 1526-1537. [CrossRef]

95. Day, R.B.; Bhattacharya, D.; Nagasawa, T.; Link, D.C. Granulocyte colony-stimulating factor reprograms bone marrow stromal cells to actively suppress B lymphopoiesis in mice. Blood 2015, 125, 3114-3117. [CrossRef]

96. Colombo, M.; Raposo, G.; Théry, C. Biogenesis, Secretion, and Intercellular Interactions of Exosomes and Other Extracellular Vesicles. Annu. Rev. Cell Dev. Biol. 2014, 30, 255-289. [CrossRef]

97. Biancone, L.; Bruno, S.; Deregibus, M.C.; Tetta, C.; Camussi, G. Therapeutic potential of mesenchymal stem cell-derived microvesicles. Nephrol. Dial. Transplant. 2012, 27, 3037-3042. [CrossRef]

98. Katsuda, T.; Kosaka, N.; Takeshita, F.; Ochiya, T. The therapeutic potential of mesenchymal stem cell-derived extracellular vesicles. Proteomics 2013, 13, 1637-1653. [CrossRef]

99. Morrison, T.J.; Jackson, M.V.; Cunningham, E.K.; Kissenpfennig, A.; McAuley, D.F.; O'Kane, C.M.; Krasnodembskaya, A.D. Mesenchymal Stromal Cells Modulate Macrophages in Clinically Relevant Lung Injury Models by Extracellular Vesicle Mitochondrial Transfer. Am. J. Respir. Crit. Care Med. 2017, 196, 1275-1286. [CrossRef]

100. Chamberlain, C.S.; Clements, A.E.B.; Kink, J.A.; Choi, U.; Baer, G.S.; Halanski, M.A.; Hematti, P.; Vanderby, R. Extracellular Vesicle-Educated Macrophages Promote Early Achilles Tendon Healing. Stem Cells 2019, 37, 652-662. [CrossRef]

101. Willis, G.R.; Fernandez-Gonzalez, A.; Anastas, J.; Vitali, S.H.; Liu, X.; Ericsson, M.; Kwong, A.; Mitsialis, S.A.; Kourembanas, S. Mesenchymal Stromal Cell Exosomes Ameliorate Experimental Bronchopulmonary Dysplasia and Restore Lung Function through Macrophage Immunomodulation. Am. J. Respir. Crit. Care Med. 2018, 197, 104-116. [CrossRef]

102. Lo Sicco, C.; Reverberi, D.; Balbi, C.; Ulivi, V.; Principi, E.; Pascucci, L.; Becherini, P.; Bosco, M.C.; Varesio, L.; Franzin, C.; et al. Mesenchymal Stem Cell-Derived Extracellular Vesicles as Mediators of Anti-Inflammatory Effects: Endorsement of Macrophage Polarization. Stem Cells Transl. Med. 2017, 6, 1018-1028. [CrossRef]

103. Hyvärinen, K.; Holopainen, M.; Skirdenko, V.; Ruhanen, H.; Lehenkari, P.; Korhonen, M.; Käkelä, R.; Laitinen, S.; Kerkelä, E. Mesenchymal Stromal Cells and Their Extracellular Vesicles Enhance the Anti-Inflammatory Phenotype of Regulatory Macrophages by Downregulating the Production of Interleukin (IL)-23 and IL-22. Front. Immunol. 2018, 9, 771. [CrossRef]

104. Reis, M.; Mavin, E.; Nicholson, L.; Green, K.; Dickinson, A.M.; Wang, X.-N. Mesenchymal Stromal Cell-Derived Extracellular Vesicles Attenuate Dendritic Cell Maturation and Function. Front. Immunol. 2018, 9, 2538. [CrossRef]

105. Del Fattore, A.; Luciano, R.; Pascucci, L.; Goffredo, B.M.; Giorda, E.; Scapaticci, M.; Fierabracci, A.; Muraca, M. Immunoregulatory Effects of Mesenchymal Stem Cell-Derived Extracellular Vesicles on T Lymphocytes. Cell Transplant. 2015, 24, 2615-2627. [CrossRef] 
106. Budoni, M.; Fierabracci, A.; Luciano, R.; Petrini, S.; Di Ciommo, V.; Muraca, M. The Immunosuppressive Effect of Mesenchymal Stromal Cells on B Lymphocytes is Mediated by Membrane Vesicles. Cell Transplant. 2013, 22, 369-379. [CrossRef]

107. Zhang, B.; Yin, Y.; Lai, R.C.; Tan, S.S.; Choo, A.B.H.; Lim, S.K. Mesenchymal Stem Cells Secrete Immunologically Active Exosomes. Stem Cells Dev. 2013, 23, 1233-1244. [CrossRef]

108. Wen, D.; Peng, Y.; Liu, D.; Weizmann, Y.; Mahato, R.I. Mesenchymal stem cell and derived exosome as small RNA carrier and Immunomodulator to improve islet transplantation. J. Control. Release 2016, 238, 166-175. [CrossRef]

109. Tamura, R.; Uemoto, S.; Tabata, Y. Immunosuppressive effect of mesenchymal stem cell-derived exosomes on a concanavalin A-induced liver injury model. Inflamm. Regen. 2016, 36, 26. [CrossRef]

110. Wen, S.; Dooner, M.; Cheng, Y.; Papa, E.; Del Tatto, M.; Pereira, M.; Deng, Y.; Goldberg, L.; Aliotta, J.; Chatterjee, D.; et al. Mesenchymal stromal cell-derived extracellular vesicles rescue radiation damage to murine marrow hematopoietic cells. Leukemia 2016, 30, 2221-2231. [CrossRef]

111. Bruno, S.; Tapparo, M.; Collino, F.; Chiabotto, G.; Deregibus, M.C.; Soares Lindoso, R.; Neri, F.; Kholia, S.; Giunti, S.; Wen, S.; et al. Renal Regenerative Potential of Different Extracellular Vesicle Populations Derived from Bone Marrow Mesenchymal Stromal Cells. Tissue Eng. Part A 2017, 23, 1262-1273. [CrossRef]

112. Le Blanc, K.; Rasmusson, I.; Sundberg, B.; Götherström, C.; Hassan, M.; Uzunel, M.; Ringdén, O. Treatment of severe acute graft-versus-host disease with third party haploidentical mesenchymal stem cells. Lancet 2004, 363, 1439-1441. [CrossRef]

113. Le Blanc, K.; Frassoni, F.; Ball, L.; Locatelli, F.; Roelofs, H.; Lewis, I.; Lanino, E.; Sundberg, B.; Bernardo, M.E.; Remberger, M.; et al. Mesenchymal stem cells for treatment of steroid-resistant, severe, acute graft-versus-host disease: A phase II study. Lancet 2008, 371, 1579-1586. [CrossRef]

114. Prasad, V.K.; Lucas, K.G.; Kleiner, G.I.; Talano, J.A.M.; Jacobsohn, D.; Broadwater, G.; Monroy, R.; Kurtzberg, J. Efficacy and Safety of Ex Vivo Cultured Adult Human Mesenchymal Stem Cells (Prochymal ${ }^{\mathrm{TM}}$ ) in Pediatric Patients with Severe Refractory Acute Graft-Versus-Host Disease in a Compassionate Use Study. Biol. Blood Marrow Transplant. 2011, 17, 534-541. [CrossRef]

115. Kurtzberg, J.; Prockop, S.; Teira, P.; Bittencourt, H.; Lewis, V.; Chan, K.W.; Horn, B.; Yu, L.; Talano, J.-A.; Nemecek, E.; et al. Allogeneic Human Mesenchymal Stem Cell Therapy (Remestemcel-L, Prochymal) as a Rescue Agent for Severe Refractory Acute Graft-versus-Host Disease in Pediatric Patients. Biol. Blood Marrow Transplant. 2014, 20, 229-235. [CrossRef]

116. von Bonin, M.; Stölzel, F.; Goedecke, A.; Richter, K.; Wuschek, N.; Hölig, K.; Platzbecker, U.; Illmer, T.; Schaich, M.; Schetelig, J.; et al. Treatment of refractory acute GVHD with third-party MSC expanded in platelet lysate-containing medium. Bone Marrow Transplant. 2008, 43, 245. [CrossRef]

117. Lucchini, G.; Introna, M.; Dander, E.; Rovelli, A.; Balduzzi, A.; Bonanomi, S.; Salvadè, A.; Capelli, C.; Belotti, D.; Gaipa, G.; et al. Platelet-lysate-Expanded Mesenchymal Stromal Cells as a Salvage Therapy for Severe Resistant Graft-versus-Host Disease in a Pediatric Population. Biol. Blood Marrow Transplant. 2010, 16, 1293-1301. [CrossRef]

118. Ciccocioppo, R.; Bernardo, M.E.; Sgarella, A.; Maccario, R.; Avanzini, M.A.; Ubezio, C.; Minelli, A.; Alvisi, C.; Vanoli, A.; Calliada, F.; et al. Autologous bone marrow-derived mesenchymal stromal cells in the treatment of fistulising Crohn's disease. Gut 2011, 60, 788-798. [CrossRef]

119. Forbes, G.M.; Sturm, M.J.; Leong, R.W.; Sparrow, M.P.; Segarajasingam, D.; Cummins, A.G.; Phillips, M.; Herrmann, R.P. A Phase 2 Study of Allogeneic Mesenchymal Stromal Cells for Luminal Crohn's Disease Refractory to Biologic Therapy. Clin. Gastroenterol. Hepatol. 2014, 12, 64-71. [CrossRef]

120. Dhere, T.; Copland, I.; Garcia, M.; Chiang, K.Y.; Chinnadurai, R.; Prasad, M.; Galipeau, J.; Kugathasan, S. The safety of autologous and metabolically fit bone marrow mesenchymal stromal cells in medically refractory Crohn's disease-A phase 1 trial with three doses. Aliment. Pharmacol. Ther. 2016, 44, 471-481. [CrossRef]

121. Bonab, M.; Yazdanbakhsh, S.; Lotfi, J.; Alimoghaddom, K.; Talebian, F.; Hooshmand, F.; Ardeshir, G.; Nikbin, B. Does Mesenchymal Stem Cell Therapy Help Multiple Sclerosis Patients? Report of a Pilot Study. Iran. J. Immunol. 2007, 4, 50-57.

122. Yamout, B.; Hourani, R.; Salti, H.; Barada, W.; El-Hajj, T.; Al-Kutoubi, A.; Herlopian, A.; Baz, E.K.; Mahfouz, R.; Khalil-Hamdan, R.; et al. Bone marrow mesenchymal stem cell transplantation in patients with multiple sclerosis: A pilot study. J. Neuroimmunol. 2010, 227, 185-189. [CrossRef] 
123. Connick, P.; Kolappan, M.; Crawley, C.; Webber, D.J.; Patani, R.; Michell, A.W.; Du, M.-Q.; Luan, S.-L.; Altmann, D.R.; Thompson, A.J.; et al. Autologous mesenchymal stem cells for the treatment of secondary progressive multiple sclerosis: An open-label phase 2a proof-of-concept study. Lancet Neurol. 2012, 11, 150-156. [CrossRef]

124. Mesples, A.; Majeed, N.; Zhang, Y.; Hu, X. Early immunotherapy using autologous adult stem cells reversed the effect of anti-pancreatic islets in recently diagnosed type 1 diabetes mellitus: Preliminary results. Med. Sci. Monit. Int. Med. J. Exp. Clin. Res. 2013, 19, 852-857.

125. Carlsson, P.-O.; Schwarcz, E.; Korsgren, O.; Le Blanc, K. Preserved $\beta$-Cell Function in Type 1 Diabetes by Mesenchymal Stromal Cells. Diabetes 2015, 64, 587-592. [CrossRef]

126. Kim, H.-S.; Lee, J.H.; Roh, K.-H.; Jun, H.J.; Kang, K.-S.; Kim, T.-Y. Clinical Trial of Human Umbilical Cord Blood-Derived Stem Cells for the Treatment of Moderate-to-Severe Atopic Dermatitis: Phase I/IIa Studies. Stem Cells 2017, 35, 248-255. [CrossRef]

127. Ferrara, J.L.M.; Levine, J.E.; Reddy, P.; Holler, E. Graft-versus-host disease. Lancet Lond. Engl. 2009, 373, 1550-1561. [CrossRef]

128. Lee, D.K.; Song, S.U. Immunomodulatory mechanisms of mesenchymal stem cells and their therapeutic applications. Spec. Issue Stem Cell Immunol. 2018, 326, 68-76. [CrossRef]

129. Ciccocioppo, R.; Gallia, A.; Sgarella, A.; Kruzliak, P.; Gobbi, P.G.; Corazza, G.R. Long-Term Follow-Up of Crohn Disease Fistulas After Local Injections of Bone Marrow-Derived Mesenchymal Stem Cells. Mayo Clin. Proc. 2015, 90, 747-755. [CrossRef]

130. Dulamea, A. Mesenchymal stem cells in multiple sclerosis-Translation to clinical trials. J. Med. Life 2015, 8, 24-27.

131. Freitag, J.; Bates, D.; Boyd, R.; Shah, K.; Barnard, A.; Huguenin, L.; Tenen, A. Mesenchymal stem cell therapy in the treatment of osteoarthritis: Reparative pathways, safety and efficacy-A review. BMC Musculoskelet. Disord. 2016, 17, 230. [CrossRef]

(C) 2019 by the authors. Licensee MDPI, Basel, Switzerland. This article is an open access article distributed under the terms and conditions of the Creative Commons Attribution (CC BY) license (http://creativecommons.org/licenses/by/4.0/). 